\title{
Journal of Transport and Supply Chain Management - Editorial
}

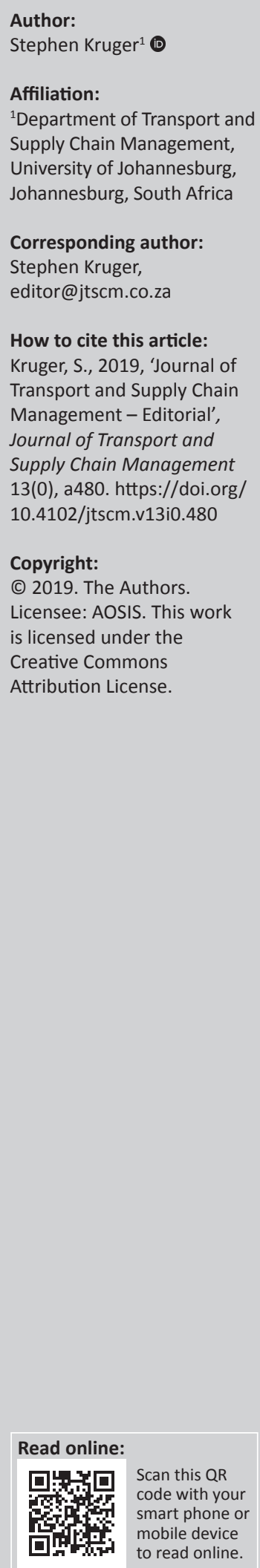

Scan this $Q R$ code with your smart phone or mobile device to read online.

\section{From the Editor's desk}

The Department of Transport and Supply Chain Management at the University of Johannesburg proudly presents you with Volume 13,2019, of the Journal of Transport and Supply Chain Management (JTSCM), a unique and accredited publication in South Africa. This journal is the only one of its kind in South Africa.

\section{Fields of study}

The journal continues to serve as an independent publication for scientific contributions in the field of transportation and supply chain management, including procurement, service quality and customer satisfaction. Thank you to all of the authors and reviewers (national and international) who have worked hard to make this journal an interesting and varied publication.

This edition of the journal contributes articles that have been reviewed and revised by national and international panel members who are acknowledged scholars and authors in the field.

This year the total contribution of high-quality articles was 14. The emphasis is on high-quality articles instead of high volume.

Articles that were submitted and approved were from the following institutions: University of Johannesburg, University of Stellenbosch, University of Pretoria, University of South Africa (Unisa), University of Cape Town, Twane University of Technology, Graduate School of Business Leadership (Unisa), University of Cape Coast and University of Addis Ababa.

A wide variety of topics (to name a few) are dealt with in this volume:

Supply Chain: Service quality and customer satisfaction skills framework for supply chains, trade logistics relevance of supply chain dominance, in the bus industry, automotive supply chains, demand planning, coal export logistics, supply chain drivers in the tourism industry and dyadic buyer and supplier relationships.

Transport: Inter-urban freight mode and funding of roads in South Africa.

Our aim is to increase the number of articles from academics, researchers and practitioners from abroad and specifically from the African continent.

I would like to thank everybody involved in this publication.

Editor

\section{Acknowledgements \\ Competing interests}

The author declares that no competing interests exist.

\section{Author's contributions}

I declare that I am the sole author of this research article. 